\title{
MANIFESTASI NEUROPSIKIATRIK PADA LUPUS ERITEMATOSUS SISTEMIK DI RSUD DR. SOETOMO SURABAYA
}

\author{
NEUROPSYCHIATRIC MANIFESTATION AMONG SYSTEMIC LUPUS \\ ERYTHEMATOSUS PATIENTS IN GENERAL HOSPITAL SURABAYA
}

Nadya Rinda Eka Rana, * Awalia, ** Yetti Hernaningsih, *** Hanik Badriyah Hidayati****

\section{ABSTRACT}

Introduction: Systemic lupus erythematosus (SLE) is a chronic autoimmune inflammatory disease with unknown causes and extensive clinical manifestations and diverse disease pathways. The clinical manifestations of SLE are very diverse, including the involvement of the nervous system and psychiatric syndrome (neuropsychiatric). Surabaya.

Aims: To describe clinical neuropsychiatric manifestations of patients with SLE in Soetomo General Hospital

Methods: This was a cross-sectional study based on medical record data on all SLE patients treated at Dr. Soetomo Hospital Surabaya, from January-December 2017. Neuropsychiatric manifestations assessment were based on the nomenclature of the American College of Rheumatology (ACR) in 1999.

Results: There were 49 patients, mostly women (98\%) with mean age 30,8 10,2 years old. Neurological manifestation was the $3^{\text {rd }}$ most common diagnosis (43\%) after hematologic disorder (73.5\%) arthritis (53.1\%). The manifestations of neuropsychiatric manifestation were mainly seizures $(40.8 \%)$, headache (34.7\%), cerebrovascular disease (26.5\%), acute confusional state (20.4\%), cognitive dysfunction (6.1\%), and polyneuropathy (8.2\%).

Discussion: The most common neuropsychiatric clinical features in SLE patients are seizures, headache, cerebrovascular disease, and acute confusional state.

Keywords: Lupus neuropsychiatry, prevalence, systemic lupus erythematosus

\section{ABSTRAK}

Pendahuluan: Lupus eritematosus sistemik (LES) merupakan penyakit inflamasi autoimun kronik yang belum diketahui penyebabnya dengan perjalanan penyakit yang luas. Manifestasi klinis LES sangat beragam, antara lain keterlibatan sistem saraf dan sindrom psikiatri (neuropsikiatri).

Tujuan: Untuk mengetahui manifestasi neuropsikiatrik pasien dengan LES di RSUD Dr. Soetomo, Surabaya.

Metodologi: Penelitian potong lintang berdasarkan data rekam medik terhadap semua pasien LES yang dirawat di RSUD Dr. Soetomo, Surabaya, pada bulan Januari hingga Desember 2017. Manifestasi neuropsikiatrik dinilain berdasarkan nomenklatur American College of Rheumatology (ACR) tahun 1999.

Hasil: Didapatkan 49 subjek yang hampir semuanya (98\%) adalah perempuan dengan rerata usia 30,8 $\pm 10,2$ tahun. Gangguan neurologis merupakan ketiga tersering (43\%) setelah gangguan hematologi $(73,5 \%)$ dan artritis $(53,1 \%)$. Manifestasi neuropsikiatri terutama kejang $(40,8 \%)$, nyeri kepala $(34,7 \%)$, penyakit serebrovaskular $(26,5 \%)$, keadaan konfusi akut $(20,4 \%)$, dan polineuropati $(8,2 \%)$.

Diskusi: Manifestasi klinis neuropsikiatri yang paling banyak dialami oleh pasien LES adalah kejang, nyeri kepala, penyakit serebrovaskular, dan keadaan konfusi akut.

Kata kunci: Lupus eritematosus sistemik, manifestasi klinis, neuropsikiatri

*FK Universitas Airlangga, Surabaya; **Departemen Penyakit Dalam FK Universitas Airlangga/RSUD Dr. Soetomo, Surabaya; ***Departemen Patologi Klinik FK Universitas Airlangga/RSUD Dr. Soetomo, Surabaya; ****Departemen Neurologi FK Universitas Airlangga/RSUD Dr. Soetomo, Surabaya. Korespondensi: hanikhidayati@yahoo.com.

\section{PENDAHULUAN}

Lupus eritematosus sistemik (LES) merupakan penyakit inflamasi autoimun kronik dengan penyebab yang belum diketahui, memiliki manifestasi klinis yang luas dan perjalanan penyakit yang beragam. ${ }^{1-2}$ Penyakit ini dapat menyebabkan inflamasi dan merusak berbagai organ tubuh, seperti persendian, kulit, ginjal, jantung, paru-paru, pembuluh darah, dan otak..$^{3-4}$ Manifestasi klinis LES sangat beragam, yang salah satunya adalah keterlibatan sistem saraf dan sindrom psikiatri (neuropsikiatri).

Manifestasi neuropsychiatric systemic lupus erythematosus (NPSLE) meliputi sindroma psikiatri dan neurologis yang melibatkan sistem saraf pusat, perifer, dan otonom pada pasien LES yang penyebab lain telah disingkirkan. ${ }^{5}$ Mekanisme patogenesis utama yang menyebabkan keterlibatan gangguan sistem saraf pada LES ada 2, yaitu autoimun dan 
vaskuler. Proses autoimun atau inflamasi karena autoantibodi atau mediator inflamasi akibat gangguan pada sawar darah otak atau pembentukan intratekal dari kompleks imun dan munculnya mediator inflamasi. Mekanisme patogenesis yang kedua, yaitu jejas vaskuler dan oklusi berupa proses trombotik pembuluh darah intrakranial besar maupun kecil akibat jejas vaskuler yang dimediasi oleh autoantibodi, kompleks imun, leukoaglutinasi, dan mempercepat terjadinya aterosklerosis. ${ }^{6}$

NPSLE cukup memberatkan dalam hal kualitas hidup, komorbiditas psikologis, dan bahkan mortalitas. Kualitas hidup yang lebih rendah ditemukan pada pasien LES dengan manifestasi neuropsikiatrik, termasuk disfungsi neurologis, psikologis-emosional, atau disfungsi kognitif, dibandingkan pasien LES tanpa manifestasi neuropsikiatrik. Tingkat kematian pada pasien NPSLE juga meningkat 10 kali lipat dibandingkan dengan pasien LES lainnya. ${ }^{7}$

Mendiagnosis pasien NPSLE di antara pasien LES cukup sulit karena spektrum gejala pendataan untuk meningkatkan kesadaran dokter akan diagnosis NPSLE, hingga mampu melakukan manajemen terapi dengan baik.

\section{TUJUAN}

Mengetahui gambaran manifestasi klinis pasien NPSLE di RSUD Dr. Soetomo, Surabaya.

\section{METODE}

Penelitian potong lintang terhadap semua pasien LES yang mengunjungi Poli Reumatologi RSUD Dr. Soetomo, Surabaya selama Januari hingga Desember 2017. Kriteria inklusi adalah pasien LES yang pernah dan sedang mengalami manifestasi neuropsikiatrik yang diagnosisnya tertulis di rekam medik.

Analisis dilakukan secara deskriptif menggunakan SPPS versi 22. Manifestasi neuropsikiatrik pada penelitian ini menggunakan nomenklatur ACR tahun 1999 (Tabel 1). ${ }^{9}$ Subjek dapat memiliki lebih dari 1 tipe kejadian manifestasi NPSLE, namun episode NPSLE yang berulang dengan manifestasi yang sama hanya dicatat sekali.

Tabel 1. Sindrom Neuropsychiatric Systemic Lupus Erythematosus menurut ACR (1999) ${ }^{9}$

\begin{tabular}{lll}
\hline Sindrom Neuropsikiatrik & \multicolumn{1}{c}{ Sistem Saraf Pusat } & \multicolumn{1}{c}{ Sistem Saraf Perifer } \\
\hline Sindrom neurologis dan fokal & 1. Meningitis aseptik & 1. Polineuropati \\
& 2. Penyakit serebrovaskular & 2. Pleksopati \\
& 3. Sindrom demielinisasi & 3. Mononeuropati (tunggal/multipleks) \\
& 4. Nyeri kepala (termasuk migren dan & 4. Sindrom Guillain-Barre \\
& hipertensi intrakranial ringan) & \\
& 5. Gangguan gerak (korea) & 5. Gangguan otonom \\
& 6. Mielopati & 6. Miastenia gravis \\
& 7. Kejang & 7. Neuropati kranial \\
1. Keadaan konfusi akut & \\
2. Gangguan cemas & \\
3. Disfungsi kognitif & \\
& 4. Gangguan mood & \\
5. Psikosis & \\
\hline
\end{tabular}

ACR: American College of Rheumatology.

neuropsikiatrik yang cukup luas dan sebagian besar tidak spesifik. ${ }^{7-8}$ Pada tahun 1999, American College of Rheumatology (ACR) mengeluarkan klasifikasi dalam mendiagnosis NPSLE yang meliputi 12 manifestasi sistem saraf pusat dan 7 manifestasi sistem saraf perifer. ${ }^{9}$ Oleh karena itu, diperlukan

\section{HASIL}

Dari 620 pasien LES pada tahun 2017, terdapat 49 subjek (7,9\%) dengan manifestasi neuropsikiatrik. Rerata usia subjek adalah 30,8 10,2 tahun dengan mayoritas perempuan (98\%). Gambar 1 menunjukkan distribusi kriteria diagnosis subjek saat didiagnosis 
LES pertama kali. Gangguan neurologis dan antinucleus antibody (ANA) yang positif merupakan ketiga tersering (43\%) setelah gangguan hematologi $(73,5 \%)$ dan artritis $(53,1 \%)$.
Manifestasi neurologis pada sistem saraf pusat tersering subjek adalah kejang $(40,8 \%)$, nyeri kepala $(34,7 \%)$, penyakit serebrovaskular $(26,5 \%)$, dan gangguan kognitif $(6,1 \%)$. Adapun

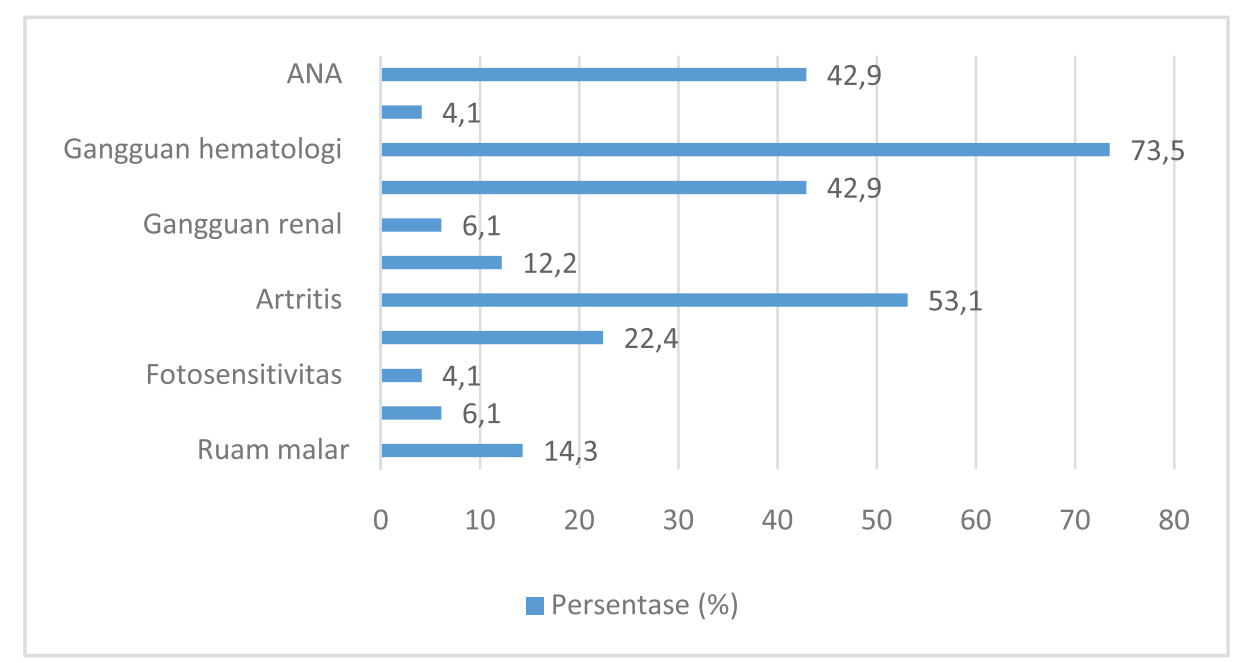

Gambar 1. Grafik Distribusi Kriteria LES dengan Manifestasi Neuropsikiatrik

(ANA: antinucleus antibody)

Tabel 2. Perbandingan Frekuensi Manifestasi Neuropsikiatrik dengan Penelitian Lain

\begin{tabular}{|c|c|c|c|c|c|}
\hline Manifestasi Klinis & Penelitian Ini & $\begin{array}{l}\text { Hajighaemi dkk } \\
\qquad(2016)^{10}\end{array}$ & $\begin{array}{l}\text { Monahan dkk } \\
(2017)^{11}\end{array}$ & $\begin{array}{l}\text { Putra dkk } \\
(2017)^{7}\end{array}$ & $\begin{array}{l}\text { Ahn dkk } \\
(2018)^{12}\end{array}$ \\
\hline Jumlah pasien NPSLE & 49 & 121 & 98 & 97 & 429 \\
\hline Insiden NPSLE & $8 \%$ & $21,7 \%$ & $39,7 \%$ & - & $38,3 \%$ \\
\hline Meningitis aseptik & - & $0,8 \%$ & $0,4 \%$ & $37,1 \%$ & $1,4 \%$ \\
\hline Penyakit serebrovaskular & $26,5 \%$ & $38,8 \%$ & $17,8 \%$ & $2,1 \%$ & $4,2 \%$ \\
\hline Nyeri kepala & $34,7 \%$ & $38,8 \%$ & $4,9 \%$ & $57,7 \%$ & $23 \%$ \\
\hline Mielopati & $4,1 \%$ & $5,7 \%$ & $2 \%$ & - & $0,3 \%$ \\
\hline Kejang & $40,8 \%$ & $26,4 \%$ & $5,3 \%$ & 14,4 & $6,3 \%$ \\
\hline Konfusi akut & $20,4 \%$ & - & $1,6 \%$ & $48,5 \%$ & $1,7 \%$ \\
\hline Gangguan kognitif & $6,1 \%$ & $11,6 \%$ & $19,8 \%$ & & $1,1 \%$ \\
\hline Gangguan mood & $6,1 \%$ & $5 \%$ & $10,5 \%$ & $73,2 \%$ & $7,9 \%$ \\
\hline Psikosis & $2 \%$ & $26,4 \%$ & $3,6 \%$ & $12,4 \%$ & $2,3 \%$ \\
\hline Gangguan cemas & - & $8 \%$ & $2,4 \%$ & $48,5 \%$ & $3,2 \%$ \\
\hline Gangguan gerak (korea) & - & $3,3 \%$ & $1,6 \%$ & $7,2 \%$ & $0,6 \%$ \\
\hline Sindrom demielinisasi & - & $7,4 \%$ & $0,4 \%$ & $10,3 \%$ & $0,2 \%$ \\
\hline Neuropati kranial & - & $16,5 \%$ & $0,8 \%$ & $5,2 \%$ & $1,3 \%$ \\
\hline Sindrom Guillain-Barre & $2 \%$ & - & - & $30,9 \%$ & $0,1 \%$ \\
\hline Gangguan otonom & $2 \%$ & $2,5 \%$ & - & $23,7 \%$ & $0,1 \%$ \\
\hline Polineuropati & $8,2 \%$ & $5 \%$ & $2 \%$ & $39,2 \%$ & $2,5 \%$ \\
\hline Pleksopati & - & $5,7 \%$ & - & $33 \%$ & - \\
\hline Mononeuropati & - & $5,8 \%$ & - & $51,2 \%$ & $2,0 \%$ \\
\hline Miastenia gravis & - & $8,2 \%$ & - & $6,2 \%$ & - \\
\hline
\end{tabular}

*Pada penelitian Putra dkk ${ }^{7}$ keadaan konfusi akut dan disfungsi kognitif digabungkan menjadi satu; NPSLE: neuropsychiatric systemic lupus erythematosus. 
manifestasi psikiatri berupa keadaan konfusi akut $(20,4 \%)$, gangguan mood $(6,1 \%)$, dan psikosis $(2 \%)$. Polineuropati $(8,2 \%)$, mielopati $(4,1 \%)$, sindrom Guillain-Barre (2\%), dan gangguan otonom $(2 \%)$ merupakan manifestasi neurologis pada sistem saraf perifer.

Sebanyak 46,9\% subjek memiliki lebih dari 1 tipe kejadian manifestasi NPSLE, sisanya hanya meiliki 1 tipe. Dilakukan pembandingan antara prevalensi total subjek NPSLE serta setiap manifestasi neuropsikiatrik pada penelitian ini dan penelitian lain (Tabel 2).

\section{PEMBAHASAN}

Lupus banyak ditemukan pada perempuan usia produktif, sesuai hasil pada penelitian ini, yaitu 98\% perempuan dengan rerata usia 30,8 tahun. ${ }^{13}$ Karakteristik ini tidak jauh berbeda dengan penelitian Mumtaz dkk yang mendapatkan 96\% subjek perempuan dengan rerata usia 30,99 tahun ${ }^{14}$ dan Putra dkk, yaitu 97\% perempuan dengan rerata usia 33 (16-61) tahun. ${ }^{7}$

Pada penelitian ini, kriteria LES yang paling sering muncul adalah gangguan hematologi (anemia, leukopenia, trombositopenia, dan limfopenia), artritis, dan gangguan neurologi. Manifestasi artritis yang paling sering adalah nyeri sendi, sedangkan gangguan neurologi tersering adalah kejang. Ahn dkk mendapatkan 38,3\% pasien NPSLE dengan kriteria LES yang paling sering muncul, yaitu tes ANA yang positif, gangguan hematologi, dan gangguan imunologi. ${ }^{12}$ Perbedaan juga ditemukan pada penelitian yang dilakukan oleh Putra dkk yang mendapatkan data bahwa 97 pasien NPSLE dengan kriteria LES yang paling sering muncul adalah tes ANA yang positif, artritis, dan fotosensitivitas. ${ }^{7}$

Perbedaan hasil penelitian ini dengan penelitian lain dapat disebabkan karena pada penelitian ini pemeriksaan tes ANA dan imunologi tidak selalu didapatkan pada rekam medik subjek, karena RSUD Dr. Soetomo, Surabaya merupakan rumah sakit primer yang menerima rujukan dari wilayah lain, sehingga hasil tes ANA dan imunologi tidak selalu dibawa oleh pasien. Perbedaan yang lain adalah pengambilan data manifestasi klinis yang tercatat di rekam medik adalah manifestasi klinis yang muncul sewaktu, sedangkan pada penelitian lain dilakukan observasi beberapa tahun serta menggunakan kuesioner. Kriteria LES pada pasien NPSLE sangat beragam dan tidak selalu muncul bersamaan.

Kejadian LES dengan manifestasi neuropsikiatrik dikategorikan menurut kriteria ACR (1999) dengan definisi kasus sebanyak 19 sindrom neuropsikiatri. Subjek LES dapat menderita lebih dari satu manifestasi klinis neuropsikiatrik, yang mungkin terkait dengan LES itu sendiri atau dengan penyebab non-LES, seperti efek samping terapi, infeksi, abnormalitas metabolik, atau keadaan sistemik lainnya, tanpa standar baku untuk mendiagnosis NPSLE. ${ }^{9}$

Tabel 2 merupakan perbandingan penelitian ini dan penelitian lain. Penelitian yang Hajighaemi dkk merupakan penelitian retrospective cross-sectional pada tahun 2004 hingga 2010 mendapatkan insiden NPSLE 21,7\%. ${ }^{13}$ Adapun penelitian Monahan dkk tahun 2007 hingga 2015 mendapatkan insiden 39,7\%. ${ }^{14}$

Penelitian Putra dkk merupakan penelitian deskriptif di Bandung selama bulan Agustus hingga Oktober 2016 terhadap 97 subjek. $^{7}$ Penelitian di Korea oleh Ahn dkk pada tahun 1998 hingga 2015 mendapatkan insiden NPSLE sebanyak 38,3\%. ${ }^{12}$ Angka-angka itu jauh lebih tinggi dibandingkan insiden NPSLE pada penelitian ini, yaitu hanya $8 \%$. Hal ini bisa disebabkan karena populasi dan wilayah yang berbeda, termasuk usia onset LES, ras, atau etnis (ras berkulit gelap seperti Hispanik dan Afrika berisiko terserang lupus lebih besar dibandingkan yang berkulit putih seperti Kaukasian) ${ }^{2}$ serta metode penelitian yang digunakan.

Pada penelitian ini manifestasi yang mendominasi adalah kejang (40,8\%). Penyebab kejang secara primer bisa diakibatkan karena aktivitas LES pada sistem saraf, tetapi mungkin juga bisa diakibatkan secara sekunder seperti hipertensi, gangguan metabolik, uremia, infeksi, atau efek samping terapi. ${ }^{15}$

Manifestasi klinis kedua tersering adalah nyeri kepala $(34,7 \%)$. Hal ini banyak ditemukan pada penelitian Hajighaemi dkk $(38,8 \%),{ }^{10}$ Putra 
dkk (57,7\%), ${ }^{7}$ dan Ahn dkk (23\%). ${ }^{12}$ Nyeri kepala pada LES ini bisa disebabkan oleh berbagai macam mekanisme, terutama disebabkan oleh hipertensi intrakranial idiopatik. ${ }^{7}$

Manifestasi lain yang cukup banyak pada penelitian ini adalah penyakit serebrovaskular (26,4\%), jauh lebih tinggi dibandingkan Putra dkk yang hanya mendapatkan 2,1\%. Hal ini diduga karena penelitian Putra dkk hanya menggunakan kuesioner, sedangkan penelitian ini mendapatkan data yang lebih lengkap berdasarkan rekam medik. Deteksi penyakit serebrovaskular cukup penting karena pasien LES memiliki peluang 2 kali lipat

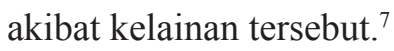

Pada penelitian ini keadaan konfusi akut juga banyak dialami oleh pasien dibandingkan dengan penelitian lainnya. Perlu dilakukan evaluasi penyebab sekunder, seperti cedera neurologis fokal, infeksi, gangguan metabolisme, maupun efek samping terapi. ${ }^{16}$

Pada penelitian ini perbedaan setiap manifestasi NPSLE bisa disebabkan karena beberapa faktor, antara lain sulitnya penentuan manifestasi neuropsikiatrik pada pasien LES. Dokter harus mendiagnosis LES terlebih dulu dan mengecualikan penyakit yang tidak berhubungan dengan LES, efek samping terapi, dan kondisi yang terkait psikososial. ${ }^{8}$

Keterbatasan penelitian ini adalah pengambilan data menggunakan data sekunder berupa rekam medik di RSUD Dr. Soetomo yang merupakan fasilitas kesehatan rujukan dari wilayah lain, sehingga manifestasi awal dan pemantauan pada pasien sering terlewatkan.

\section{KESIMPULAN}

Didapatkan insiden NPSLE sebesar 8\%, yang mayoritas (98\%) adalah perempuan pada usia produktif. Manifetasi klinis NPSLE yang paling banyak ditemukan adalah kejang, nyeri kepala, penyakit serebrovaskular, dan keadaan konfusi akut.

\section{DAFTAR PUSTAKA}

1. Perhimpunan Reumatologi Indonesia. Diagnosis dan pengelolaan lupus eritematosus sistemik. PAPDI [serial online]. 2011 [diunduh 15 Januari 2017];2011:3-41. Tersedia dari: PAPDI.
2. Pons-Estel GJ, Ugarte-Gil MF, Alarcón GS. Epidemiology of systemic lupus erythematosus. Expert Rev Clin Immunol. 2017;13(8):799-814.

3. Aly SE, Mohammed FM, Abd-Almageed AS, Ahmed GH. Comparative study for pattern of social support among systemic lupus erythematous patients at outpatient clinics, Assiut University Hospital. Am J Nurs Res. 2018;6(6):500-6.

4. Bai R, Liu S, Zhao Y, Cheng Y, Li S, Lai A, dkk. Depressive and anxiety disorders in systemic lupus erythematosus patients without major neuropsychiatric manifestations. J Immunol Res. 2016;2016:1-7.

5. Perricone C, Pendolino M, Olivieri M, Conti F, Valesini G, Alessandri C. Neuropsychiatric Manifestations associated with anti-endothelial cell antibodies in systemic lupus erythematosus. Isr Med Assoc J. 2015;17(3):171-8.

6. Magro-Checa C, Zirkzee EJ, Huizinga TW, SteupBeekman GM. Management of neuropsychiatric systemic lupus erythematosus: current approaches and future perspectives. Drugs. 2016;76(4):459-83.

7. Putra SD, Ardisasmita MN, Hamijoyo L. Neuropsychiatric manifestation screening among systemic lupus erythematosus patients in Hasan Sadikin general hospital Bandung. 2017;9(2):18-22.

8. Kivity S, Agmon-Levin N, Zandman-Goddard G, Chapman J, Shoenfeld Y. Neuropsychiatric lupus: a mosaic of clinical presentations. BMC Med. 2015;13(1):1-11.

9. Vivaldo JF, De-Amorim JC, Julio PR, De-Oliveira RJ, Appenzeller S. Definition of NPSLE: does the ACR nomenclature still hold? Front Med (Lausane). 2018;5:1-6.

10. Hajighaemi $\mathrm{F}$, Etemadifar $\mathrm{M}$, Bonakdar $\mathrm{Z}$. Neuropsychiatric manifestations in patients with systemic lupus erythematosus: a study from Iran. Adv Biomed Res. 2016;5(1):43.

11. Monahan RC, Beaart-Van-De-Voorde LJJ, SteupBeekman GM, Magro-Checa C, Huizinga TWJ, Hoekman J, dkk. Neuropsychiatric symptoms in systemic lupus erythematosus: impact on quality of life. Lupus. 2017;26(12):1252-9.

12. Ahn GY, Kim D, Won S, Song ST, Jeong HJ, Sohn IW, dkk. Prevalence, risk factors, and impact on mortality of neuropsychiatric lupus: a prospective, single-center study. Lupus. 2018;27(8):1338-47.

13. Rees F, Doherty M, Grainge MJ, Lanyon P, Zhang W. The worldwide incidence and prevalence of systemic lupus erythematosus: A systematic review of epidemiological studies. Rheumatol (United Kingdom). 2017;56(11):1945-61. 
14. Mumtaz S, Rasheed U, Zammurrad S, Aziz W. Neuropsychiatric events attributed to systemic lupus erythematosus: a single center study from pakistan. Rawal Med J. 2017;42(3):306-11.

15. Huang XY, Magder LS, Petri M. Predictors of incident seizure in systemic lupus erythematosus. J Rheumatol. 2016;43(3):565-75.
16. Chen S, Bermas B. Neuropsychiatric manifestations of systemic lupus erythematosus. Neurorheumatology. 2019;125-7. 